\title{
Occurrence Of Nematodes And Trematode Cercariae In Lymnea Species Of Danmadahun Part Of Jakara Dam, Kano State, Nigeria
}

\author{
Rabi Suraj Duwa \\ Nigeria Police Academy Wudil
}

\begin{abstract}
This paper reports the occurrence of nematodes and trematode cercariae in Lymnea species of one part of Danmadahun in Jakara dam, Kano state, Nigeria. This study was initially carried out between October to January 2017 to determine the types of trematode cercariae in freshwater snails in the water body. Freshwater snails were collected from the accessible sites on Danmadahun part of Jakara dam and placed individually in compartmented petridishes for cercarial shedding. A total of 67 Lymnea snails (made up of eight species) were collected from this part of the study site out of which four forms of nematode, Chaetogaster species and five forms of cercariae, three Gymnocephalus and two unidentified cercaria were encountered. The prevalence of nematodes in these snails is $6 \%$ and that of cercariae is $7.46 \%$ with $11.94 \%$ as the overall prevalence of infection. This study presents the first report of nematodes in snails of Jakara dam.There is the need for thorough investigation and control of Lymnea and other snail species in this area because of the diverse infections they can transmit in humans, animals and agriculture since this is an irrigation site.
\end{abstract}

Keywords: Cercariae, Danmadahun, Jakara dam, Lymnea species, Nematodes.

\section{Introduction}

Freshwater snails are important in the transmission of parasitic diseases. They have been reported as serving as intermediate hosts to parasites of man and animals (Duwa and Oyeyi,2009;Duwa,2017 and Ofoezie,2002). The different parts of Jakara dam harbour different species of snails and only the occurrence of trematode cercaria has been reported until now. Most studies carried out on the dam focused only on the presence of snails and prevalence of infection among communities around the dam. Cercariae are the free swimming larval stage of flukes of schistosomiasis and Fascioliasis. Jakara dam has been investigated for its role in the transmission of schistosomiasis but not for other diseases transmitted by snails. Different snails can carry the same type of cercaria and a single snail can carry more than one type of cercaria (Kuris and Lafferty ,1994; Sousa, 1993 and Duwa, 2017). Martins and Alves (2010) reported the occurrence of Chaetogaster limnaei K. von Baer, 1927 (Oligochaeta, Naididae) in Gastropoda mollusks in horticultural channels of Southeastern Brazil. Grewal et al (2003) reported that nematodes form diverse associations with slugs and snails that range from paratenic relationships to parasitic or pathogenic relationships and that a majority of the Metastrongyloidea (Order: Strongylida) use molluscs as intermediate hosts for which vertebrates serve as final hosts while a majority of Rhabditoidea (Order: Rhabditida) use molluscs as definitive hosts in which the entire nematode life cycle is completed. Mohammad (2015) reported the occurrence of cercariae, nematode and nematode larva in freshwater snails collected from central Iraq during cercarial shedding .

\section{Material And Methods}

2.1 Study area: This study was carried out in Danmadahun part of Jakara dam which is located between (Latitude N12 ${ }^{\circ} 05.452^{\prime}$ and Longitude $8^{\circ} 40.418^{\prime} \mathrm{E}$ ) in Gezawa local government are of Kano state. Jakara dam was constructed in 1976 and is situated in Wasai, Minjibir Local Government Area (LGA) in the North Eastern part of Kano metropolis about $41.5 \mathrm{Km}$ from the city centre. The area in terms of geology falls within the tip end of the Basement complex adjoining Chad formation, which is characterized by disappearing type of streams. Jakara dam is one of the most grossly polluted dam in West Africa, because during the dry season all the streams that feed it dry up with the exception of the major Jakara stream which sustain it. The water bodies contain muddy substrata and gentle flowing, low turbidity water with rich growth of algae and macrophytes. 


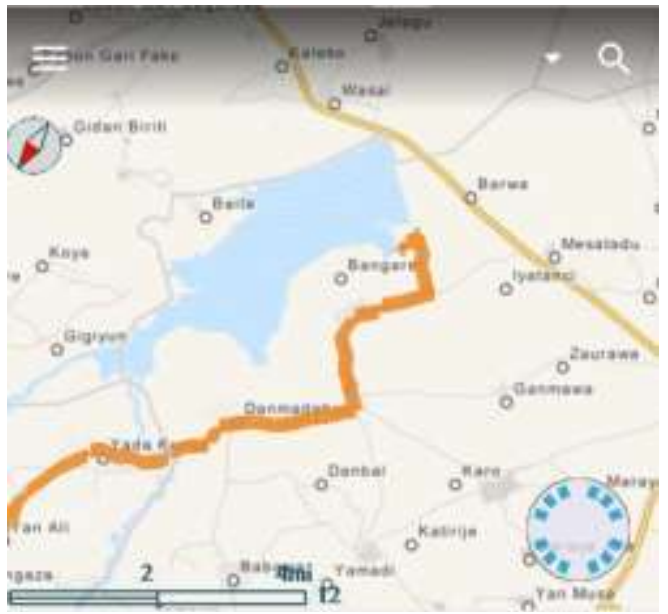

Fig.1: Map of Jakara dam

\subsection{Snail collection}

Freshwater snails were searched for and collected from two accessible sites on Danmadahun part of Jakara dam between October and January 2017. The accessible areas were reduced with each visit by farmers who cultivate the land as the water recedes after the rainy season. The sites where these snail species were collected are $300 \mathrm{~m}$ apart, one part has vegetation (water hyacinth) and habouring Lymnea and Bulinus species (reported in Duwa, 2017), the other with no vegetation containing bigger Lymnea species lying freely in water. Snails were collected by hand picking only into wide mouthed plastic containers and brought to the laboratory. It was then sorted out into different species for further investigation. These snails were fed with lettuce during this study.

\subsection{Cercarial shedding}

Snails were separately placed in compartmented petridishes and exposed to artificial light (rechargeable lamp) for 2-3 hours to stimulate cercarial shedding, they were also exposed to sunlight on a sunny day (this is harmattan period in Kano). Few drops of water was then taken from the petridish and placed on a glass slide using a pipette and narcotized with neutral red to demobilize them before examination with a compound microscope for more detailed identification. Those snails that do not shed cercaria on the first day were reexposed on the second day and those that shed cecariae were continuously exposed and observed under the microscope until the water in which they were placed was exhausted. Photomicrograph of the cercariae were taken using Toupview 3.7 digital camera fitted to the microscope through a USB. Efforts were made to identify cercariae and nematodes using keys provided by Frandsen and Christensen (1984), Key to cercarial identification and website resources. During this period, snails were fed lettuce.

\subsection{Snails discovered}

\section{Results And Discussion}

Only one family of freshwater snails was encountered in this part of Danmadahun in Jakara dam (Fig.1).Table 1 shows the frequency of snails encountered in this part of Danmadahun and the types of infection they are carrying. Altogether 67 Lymnea snails made up of eight different species were collected. The Lymnea species encountered (Fig.2) were presumably identified as Limnaeus cerasum Troschel, L.nyansae, L.elgonensis Preston, L.undussumae von Martens, 1897 Limnaeus javanicus var., A. pfefferiana Dunker, Amphipeplea cumingiana and L. kempi Preston (Fig.3). The most abundant snail is Limnaeus cerasum Troschel (19.4\%) followed by Limnaeus javanicus var (16.41\%), A. pfefferiana, Dunker (14.92\%). There are no Bulinus or other snail specie in this part of Danmadahun. Out of the 67 snails collected 8 were infected, three were harbouring nematodes (Chaetogaster species) only and four were shedding cercariae only and one shedding both cercaria and nematode.

\subsection{Cercariae and Nematodes encountered}

Four types of nematodes (Fig.5a-d), Chaetogaster species and five types of cercariae (Fig.4a-f), three Gymnocephalus (a,b and e), two unidentified cercariae (c and d) and a metacercaria (f) were encountered. The prevalence for cercarial infection is $7.46 \%$ and for nematode infection is $6 \%$ while the overall prevalence of infection is $11.94 \%$. 
Table 1: Frequency of occurrence of Lymnea species in Danmadahun 2

\begin{tabular}{|c|c|c|c|c|}
\hline Snails species & $\begin{array}{l}\text { Number } \\
\text { collected }\end{array}$ & $\begin{array}{l}\text { Number } \\
\text { infected }\end{array}$ & $\begin{array}{l}\text { Cercarial } \\
\text { infection }\end{array}$ & $\begin{array}{l}\text { Nematode } \\
\text { infection }\end{array}$ \\
\hline $\begin{array}{l}\text { Limnaeus } \\
\text { cerasum } \\
\text { Troschel }\end{array}$ & 13 & 1 & + & - \\
\hline L.nyansae & 8 & 1 & + & - \\
\hline $\begin{array}{l}\text { L.elgonensis } \\
\text { Preston }\end{array}$ & 8 & 1 & + & + \\
\hline $\begin{array}{l}\text { Limnaeus } \\
\text { vanicus var. }\end{array}$ & 11 & 1 & + & - \\
\hline $\begin{array}{l}\text { Amphipeplea } \\
\text { cumingiana }\end{array}$ & 3 & 1 & - & + \\
\hline $\begin{array}{l}\text { A. pfefferiana } \\
\text { Dunker }\end{array}$ & 10 & 1 & - & + \\
\hline $\begin{array}{ll}L . & k e m p i \\
\text { Preston } & \end{array}$ & 5 & 1 & + & - \\
\hline $\begin{array}{l}\text { L.undussumae } \\
\text { von Martens, } \\
1897\end{array}$ & 9 & 1 & - & + \\
\hline Total & 67 & 8 & 5 & 4 \\
\hline
\end{tabular}

Fig. 2(a)
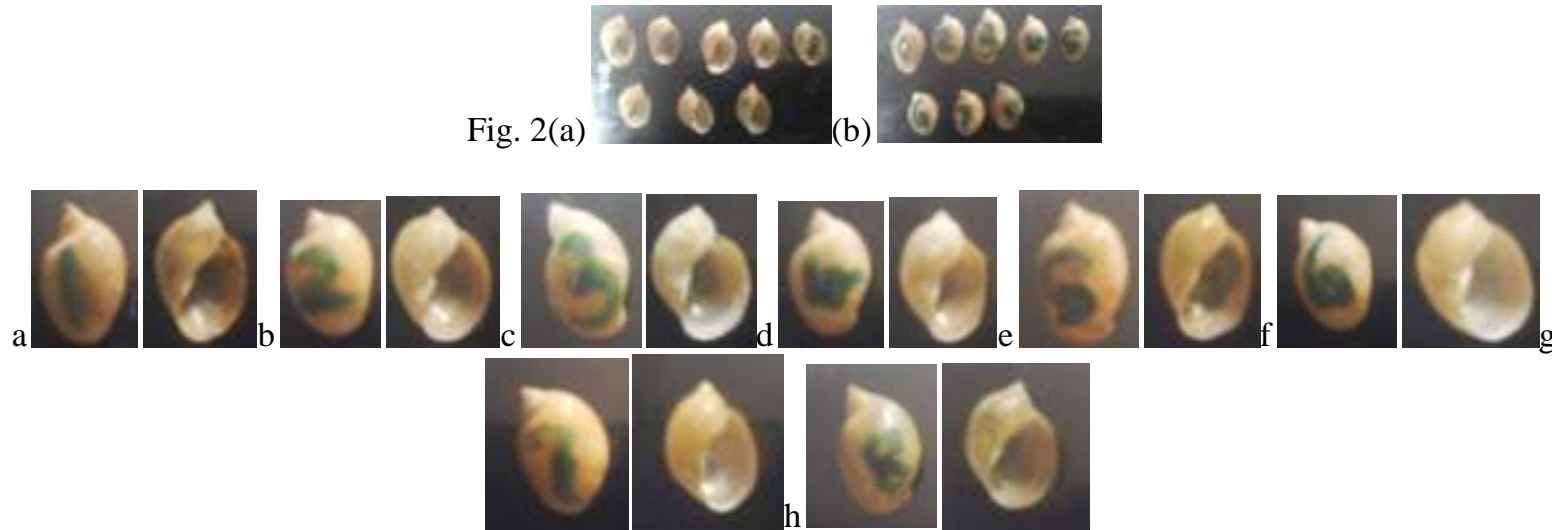

Fig.3 (a-h): Abapertural and apertural view of Lymnea species the study area

(a)Limnaeus cerasum Troschel (b) Limnaea nyansae von Martens, 1892 (c) Limnaea elgonensis Preston (d) Limnaeus javanicus var. intumescens von Martens, 1867 (e) Amphipeplea cumingiana Pfeiffer, 1845 (f) Amphipeplea pfefferiana Dunker (g) Limnaea kempi Preston, 1911 (h) Limnaea undussumae von Martens, 1897

(a)

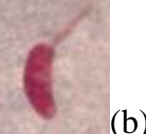

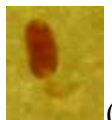

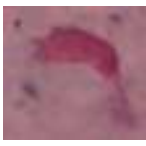

(d)
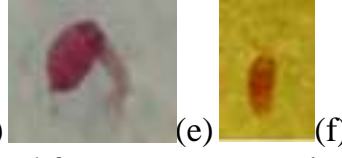

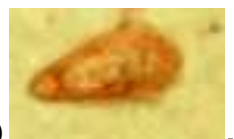

-

$\begin{array}{llll}\text { (a)Gymnocephalus cercaria (b)Gymnocephalus cercaria(c)Unidentified cercaria(d)Unidentified } & \end{array}$ cercaria(e)Gymnocephalus cercaria (f) Metacercaria

(a)
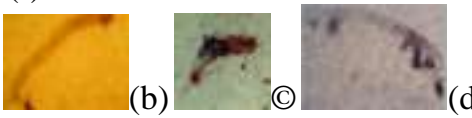

(a) Chaetogaster limnaei spp (b) Chaetogaster limnaei spp (c) Chaetogaster limnaei spp (d) Chaetogaster limnaei spp

Fig. 5a-d: Nematodes found in Lymnea species in Danmadahun part of Jakara dam

Different types of Lymnea species were found on Danmadahun part of Jakara dam. The findings on this part of Danmadahun were reported separately because of its uniqueness which is the habitat preference of the snails observed, their size and what they were parasitized by. Lymnea natalensis and other Lymnea species were found attached to the macrophyte, water hyacinth in muddy sustrata with Bulinus species in the first part 
(Duwa 2017). In this second part the snails are much bigger and were picked 300 meters away, in clear water of pH7.2. It is noteworthy that only Lymnea species were supported by this part of Danmadahun, which is in contrast with the other part 300 meters away that was dominated by Bulinus species and smaller sized Lymnea species. Since this is the first time snail species in this part of the dam were reported it cannot be ascertained whether it was dominated by other species in earlier times, farmers were found planting (cassava) as the water recedes after the rainy season (this is an irrigation system). In this part of the dam the snails were both infected with nematodes and cercariae. The nematodes encountered in this study Chaetogaster limnaei (Naidinae) has two known species that parasitize freshwater snails, one endoparasitic in the kidney and the other ectoparasitic on the outer surfaces of the host. C. limnaei limnaei was found to attach itself to the mantle cavity and pulmonary cavity of the host and feeds on microorganisms, such as protozoa, rotifers and algae (Michelson, 1964; Fried et al., 2008; Stoll et al., 2013), hence it is regarded as a commensal (Young, 1974). An experiment conducted by Stoll et al. (2013) showed that the relationship between C. limnaei limnaei and Physa acuta can be described as epizoic antibiosis at high infestation rates, due to the fact that hosts had lower growth rates and productivity. It is not known whether these nematodes can affect infection of snails by trematodes but in this study it was observed that the snails that were harbouring cercariae are not harboring any nematode and vice versa except for the case of only one snail specie (Lymnae elgonensis) which was harboring cercaria and nematode at the same time, this showed that the snail can both be infected with a nematode and a trematode. The report of Martins and Aves (2010) and Agbolade et al (2007) showed that Chaetogaster limnea were found in different snail species including Biomphlaria and Potadoma moerchi respectively, this findings proved that Chaetogaster species can use different organisms that are present in an aquatic environment as substrate since in this study they were found in Lymnea species. Earlier studies by Rodgers et al (2005) has shown that the prevalence of infection was significantly higher in snails that were not harboring $C$. limnaei limnaei relative to those that were colonized by the commensal, indicating that the oligochaete may protect the host from trematode infection, this may only happen in water bodies that favor the snail host considering the fact that these nematodes were found in snails in very clear water with no vegetation and most intermediate hosts of trematodes such as Bulinus species were mostly found attached to vegetation in muddy substrata. Although there is no report yet of Chaetogaster infecting crops a number of nematodes have been found to infect crops in farm lands thereby reducing yields. A report by Nagesh et al (2005) stated that all the four major species of Meloidogyne including; $M$.javanica, $M$. arenaria, M.incognita and $M$. hapla are known to readily attack tomato crops in outdoor as well as in indoor cultivations. About 2000 plants are susceptible to infection by the rootknot nematodes and they cause approximately $5 \%$ of global crops loss (Sasser and carter, 1985). Nematodes of M. incognita were isolated from crop roots of paprika plant and M. hapla was isolated from galls of vegetables grown in the open field in Jublijana (Sirca, et al., 2004). There is likelihood that nematodes that are harmful to agriculture or agricultural products may invade the water body. The types of associations between these snails and the nematodes they are harbouring needs to be investigated. There is also the need for further studies on the snail species in this area considering the fact that other snail species have been found as intermediate hosts of parasitic nematodes. Such studies will provide relevant information on the potential risks of Lymnea species in transmitting diseases other than Fascioliasis which is already known.

\section{References}

[1]. Agbolade, OM., Gledhil, T., Fajebe, OT., Abolade, OM. and Olateju, TM., (2007). Population, seasonal abundance, Dockovdia oruensis infection and other parasites of Potadoma moerchi in southwestern Nigeria. African Journal of Biotechnology, vol. 6, no. 6, p. 826-830.

[2]. Alan Buse (1974) The Relationship of Chaetogaster limnaei (Oligochaeta: Naididae) with a Variety of Gastropod Species The Journal of Animal Ecology, Vol. 43, No. 3 pp. 821-837 Published by: British Ecological Society

[3]. Bem, A.A, Antsa, R.T., Orpin, J.B, Bem, S.L, And Amua, Q.M (2014) Root-Knot Nematode (Meloidogyne Species) Distribution in Some Tomato Fields in Makurdi IOSR Journal of Pharmacy and Biological Sciences (IOSR-JPBS). Volume 9, Issue 4 Ver. II PP $143-146$

[4]. Betterton, C., Ndifon, G.T., Tan, R.M., (1988b). Schistosomiasis in Kano State, Nigeria, II. Field studies on aestivation in Bulinus rohlfsi (Clessin) and B. globosus (Morelet) and their susceptibility to local strains of Schistosoma haematobium (Bilharz). Annals of Tropical Medicine and Parasitology 82: 571-579.

[5]. Duwa S R (2017b) Emergence of New Snail Species and Cercariae on Jakara Dam

[6]. Fried, B., Peoples, RC., Saxton, TM. and Huffman, JE., (2008). The Association of Zygocotyle lunata and Echinostoma trivolvis with Chaetogaster limnaei, an Ectosymbiont of Helisoma trivolvis. Journal of Parasitology, vol. 94, no. 2, p. 553-554.

[7]. Frandsen, F. / Christensen, N.Ø. (1984) An introductory guide to the identification of cercariae from African freshwater snails with special reference to cercariae of trematode species of medical and veterinary importance Acta Tropica 4L 181-202 Danish Bilharziasis Laboratory. Charlottenlund. Denmark

[8]. Grewal, P.S., Grewal, S.K., Tan, L., Adams, B.J.( 2003) Parasitism of molluscs by nematodes: Types of associations and evolutionary trends. J. Nematol., 35(2): 146156.

[9]. Kuris AM, Lafferty KD (1994) Community structure: Larval trematodes in snail hosts. Annu Rev Ecol Syst, 25:189-217.

[10]. Maxim V. Vinarski (2016) Annotated type catalogue of lymnaeid snails (Mollusca, Gastropoda) in the collection of the Natural History Museum, Berlin Zoosyst. Evol. 92 (1), 131-152

[11]. Martins, RT and Alves, RG (2010) Occurrence of Chaetogaster limnaei K. von Baer, 1927 (Oligochaeta, Naididae) associated with Gastropoda mollusks in horticultural channels in Southeastern Brazil Braz. J. Biol. vol.70 no.4 
[12]. Michelson, E H., (1964) The protective action of Chaetogaster limnaei on snails exposed to Schistosoma mansoni. The Journal of Parasitology, vol. 50, no. 3, p. 441-444.

[13]. Mohammad K. Mohammad (2015) The Parasitic Infection of the Freshwater Snails Collected in Central Iraq Int.J.Curr.Microbiol.App.Sci 4(3): 47-55

[14]. Nagesh M, Hussaini S.S, Chidanandaswamy B.S, (2005). Incidence of root-knot nematode, Meloidogyne incognita on gherkin, Cucumis sativus and yield losses. Indian J. Plant Prot., 33:309-311.

[15]. Ofoezie I E (2002) Human health and sustainable water resources development in Nigeria: Schistosomiasis in artificial lakes Natural Resources Forum 26 150-160

[16]. Pinder (2003), (2010), Pinder \& Brinkhurst (1994), Williams (1980), Hawking \& Smith (1997), Gooderham \& Tsyrlin (2002) In: http://www.mdfrc.org.au/bugguide/display

[17]. https://memim.com/chaetogaster.html

[18]. Rodgers, J. K, Sandland,G. J, Joyce S. R, and Dennis J. M (2005) Multi-Species Interactions Among a Commensal (Chaetogaster limnaei limnaei), a Parasite (Schistosoma mansoni), and an Aquatic Snail Host (Biomphalaria glabrata) Journal of Parasitology 91(3):709-712

[19] Sasser, J.N., Carter C.C (1985): Overview of the International Meloidogyne project 1975-1984. In an Advance Treatise on MeltNdngyjie Edited by Sasser J.N. Carter C C Raleigh North Carolina State University Graphics. 19-24.

[20] Sirca, S; Urek, G; Karssen, G. (2004). The incidence of the root-knot nematode Meloidogyne incognita and Meloidogyne hapla in Slovenia. Acta. Agric. Slovenia, 83: 15-22.

[21] Sousa WP (1993): Interspecific antagonism and species coexistence in a diverse guild of larval trematode parasites. Ecol Monogr, 63:103-128.

[22] Stoll, S., Früh, D., Westerwald, B., Hormel, N. and Haase, P. (2013) Density-dependent relationship between Chaetogaster limnaei limnaei (Oligochaeta) and the freshwater snail Physa acuta (Pulmonata). Freshwater Science, 32: 642-649. doi:10.1899/12-072.1

[23] Young, M.R. (1974) Seasonal variation in the occurrance of Chaetogaster limnaei limnaei Gruffydd (Oligochaeta) in two of its molluscan hosts in the Worcester-Birmingham canal and its relationship with the digenean parasites of these molluscs. Journal of Natural History, 8: 529-535. 